\title{
Penetapan Masa Jabatan Jaksa Agung dalam Sistem Penetapan Jabatan Pejabat Negara
}

\author{
Titik Triwulan Tutik \\ Fakultas Syari’ah IAIN Sunan Ampel Surabaya \\ Jl. Jend. A. Yani No. 147 Surabaya, \\ tt_titik@yahoo.com
}

\begin{abstract}
This research is to examine on how the rules of law that have ever been applied to regulate the determination of term of office of an attorney general and its relationship to the system in determining the position of a state official. The research is dogmatic supported by a historical approach, statute approach, and comparative approach. The steps of the research were conducted by collecting the materials of secondary law, all of which were noted using card system based on the subjects of research problems and the writing system. The result of the research shows that the position of the attorney is between two sides - judicative and executive. As a result, it could emerge a contradiction in its regulation (dual obligation). Related to the term of office, it is found that no regulation of the Attorney of Indonesia Republic regulates about the term of office of an attorney general either definitively or restrictively. The determination of a term of office of an attorney general commonly follows the constitutional convention saying that an attorney general is appointed at the beginning of cabinet and will end by ending of the term of the office.
\end{abstract}

Key words: Determination of term of office, term of office of attorney general, the system of determining the term of office of state officials

\begin{abstract}
Abstrak
Penelitian ini mengkaji tentang bagaimana ketentuan-ketentuan hukum yang pernah berlaku mengatur mengenai penetapan masa jabatan jaksa agung dan bagaimana penetapan masa jabatan jaksa agung dalam sistem penetapan jabatan pejabat negara. Penelitian ini adalah penelitian hukum normatif (dogmatic) dengan pendekatan historis (historical approach), pendekatan perundang-undangan (statute approach), dan pendekatan perbandingan (comparative approach). Langkah penelitian dilakukan dengan menghimpun bahan-bahan hukum sekunder semuanya dicatat dengan menggunakan sistem kartu (card'system), yang disusun berdasarkan pokok permasalahan penelitian dan sistematika penulisan. Hasil penelitian menunjukkan bahwa kedudukan Kejaksaan berdiri di dua sisi, yudikatif dan eksekutif, sehingga menimbulkan kontradiksi dalam pengaturannya (dual obligation). Berkaitan dengan masa jabatan, perundang-undangan tentang Kejaksaan RI tidak ada yang mengatur secara definitif maupun limitatif berapa lama seorang Jaksa Agung menduduki jabatannya. Penetapan masa jabatan Jaksa Agung umumnya mengikuti konvensi ketatanegaraan, yakni Jaksa Agung diangkat di awal kabinet dan berakhir masa jabatannya dengan berakhirnya masa bakti kabinet itu.
\end{abstract}

Kata kunci : Penetapan masa jabatan, masa jabatan jaksa agung, sistem penetapan masa jabatan pejabat negara 


\section{Pendahuluan}

Kejaksaan Republik Indonesia sebagai salah satu institusi penegak hukum merupakan komponen dari salah satu elemen sistem hukum secara universal diberikan kewenangan melaksanakan kekuasaan negara di bidang penuntutan dan tugas-tugas lain yang ditetapkan oleh undang-undang. Dalam hal ini dapat dikatakan, bahwa kejaksaan Republik Indonesia memiliki posisi sentral dan peranan yang strategis di dalam suatu negara hukum. Posisi sentral dan peranan yang strategis ini, karena berada di poros dan menjadi filter antara proses penyidikan dan proses pemeriksaan di persidangan, di samping sebagai pelaksana penetapan dan keputusan pengadilan.

Keberadaan Kejaksaan diatur secara khusus dalam Undang-Undang Nomor 16 Tahun 2004 tentang Kejaksaan Republik Indonesia (baca: UUK 2004) sebagai subordinated dari UUDNRI 1945. Dalam UUK 2004 ini dijelaskan Kejaksaan adalah lembaga pemerintah yang melaksanakan kekuasaan negara di bidang penuntutan serta kewenangan lain berdasarkan undang-undang. ${ }^{1}$ Sementara Jaksa Agung adalah pimpinan dan penanggungjawab tertinggi Kejaksaan yang memimpin, mengendalikan pelaksanaan tugas, dan wewenang Kejaksaan. ${ }^{2}$ Status Jaksa Agung adalah pejabat negara yang diangkat dan diberhentikan oleh Presiden ${ }^{3}$ serta bertanggungjawab kepada Presiden. Dari sini jelas bahwa Jaksa Agung berada di bawah kekuasaan eksekutif, di bawah presiden. Oleh karena itu jabatan Jaksa Agung dikatakan setingkat menteri negara. Dengan demikian yang berhak mengangkat dan memberhentikannya adalah presiden, melalui Keputusan Presiden (Keppres).

Membicarakan jabatan tentu juga berkaitan dengan masa jabatan. Dalam UUK 2004 tidak dijelaskan secara definitif berapa lama masa jabatan Jaksa Agung, periode jabatan atau lama masa baktinya. Namun berdasarkan konvensi ketatanegaraan sejak Indonesia merdeka masa jabatan Jaksa Agung disamakan dengan menterimenteri sebagai anggota kabinet yang membantu presiden. Oleh karena itu masa

\footnotetext{
${ }^{1}$ Pasal 2 ayat (1) UUK 2004. Keberadaan Kejaksaan RI selanjutnya dipertegas lagi dalam Penjelasan Umum UUK 2004 yang merumuskan, "Kejaksaan sebagai lembaga pemerintahan yang melaksnakan kekuasaan negara di bidang penuntutan ditegaskan kekuasaan negara tersebut dilaksanakan secara merdeka. Oleh karena itu, kejaksaan dalam melaksanakan fungsi, tugas, dan wewenangnya terlepas dari pengarub kekuasaan pemerintah dan kekuasaan lainnya. Selanjutnya ditentukan Jaksa Agung bertanggungjawab atas penuntutan yang dilaksakan secara independen demi keadilan berdasarkan bukum dan hati nurani.. Dengan demikian Jaksa Agung selaku pimpinan kejaksaan dapat sepenubnya merumuskan dan mengendalikan arah dan kebijakan penanganan perkara untuk keberbasilan penuntutan".

${ }^{2}$ Pasal 18 ayat (1) UUK 2004

${ }^{3}$ Pasal 19 ayat (1) dan ayat (2) UUK 2004
} 
jabatannya mengikuti masa bakti presiden yaitu 5 (lima) tahun. Walaupun demikian, Presiden dengan hak prerogatifnya dapat sewaktu-waktu memberhentikannya dari jabatan dan mengangkat pejabat baru. Pengangkatan pejabat baru bisa karena satu dan lain sebab, misalnya perombakan (reshuffle) kabinet.

Pada masa Presiden Susilo Bambang Yudhoyono dan Wakil Presiden Jusuf Kalla (periode 2004-2009) terjadi 2 kali reshuffle kabinet. Pada reshuffle kabinet yang kali kedua, Hendarman Supandji dilantik menggantikan Jaksa Agung Abdurrahman Saleh. Hendarman terus menjabat hingga berakhirnya masa bakti presiden, wakil presiden dan Kabinet Indonesia Bersatu I (baca: KIB I). Kemudian pasca pemilu presiden 2009 yang dimenangkan oleh pasangan Susilo Bambang YudhoyonoBoediono, pada tanggal 20 Oktober 2009 Kabinet Indonesia Bersatu I dibubarkan dan pada tanggal yang sama diumumkan pembentukan Kabinet Indonesia Bersatu II (baca: KIB II) sekaligus pelantikannya untuk periode 2009-2014. Namun ada yang tidak biasa pada saat itu. Jaksa Agung Hendarman Supandji menjadi satu-satunya pejabat yang tidak disebut namanya dalam Keppres pemberhentian menteri-menteri KIB I dan tidak pula pada Keppres pengangkatan menteri-menteri KIB II. Hendarman justru langsung menjabat dan meneruskan tugasnya sebagai Jaksa Agung untuk periode 2009-2014. Hal inilah yang memicu diajukannya judicil review oleh Yusril Ihzamahendra terhadap Pasal 22 ayat (1) huruf d UU No. 16 Tahun 2004 tentang Kejaksaan RI kepada Mahkamah Konstitusi. Selengkapnya Pasal 22 ayat (1) menegaskan sebagai berikut: Jaksa Agung diberhentikan dengan hormat dari jabatannya karena: a. meninggal dunia; b. permintaan sendiri; c. sakit jasmani atau rohani terus-menerus; d. berakhir masa jabatannya; e. tidak lagi memenuhi salah satu syarat sebagaimana dimaksud dalam Pasal 21.

Menurut Yusril klausul huruf d tersebut tidak jelas sehingga multitafsir (polyinterpretabel) karena tidak menjelaskan dengan pasti kapan seorang Jaksa Agung dianggap berakhir masa jabatannya. Klausul itu dapat saja ditafsirkan seumur hidup ${ }^{4}$ selama tidak diberhentikan dan sebagainya. Hal ini dapat menimbulkan ketidakpastian hukum (rechsonzekerheid) sehingga Yusril mengajukan permohonan agar MK sebagai the guardian of constitution dan the final interpreter of the constitution memberikan tafsir yang pasti. ${ }^{5}$

\footnotetext{
${ }^{4}$ Menurut kesaksian Denny Indrayana, sebagai salah satu saksi ahli dari pihak pemerintah, dalam persidangan uji materi UU No. 16 Tahun 2004. Lihat putusan MK No.49/PUU-VII/2010

${ }^{5}$ http://yusril.ihzamahendra.com/2010/08/27/permohonan-uji-materil-uu-Kejaksaan-ke-mk/, diakses 1 Juli 2011
} 
Pengajuan judicial review itu telah diputus oleh MK melalui Putusannya No. 49/PUU-VIII/ 2010 tentang Pengujian Undang-Undang Nomor 16 Tahun 2004 tentang Kejaksaan RI [Pasal 22 ayat (1) huruf d] yang inti amar putusannya memberikan tafsir terhadap klausul huruf d sebagai berikut:

Pasal 22 ayat (1) huruf d UU No. 16 Tahun 2004 tentang Kejaksaan RI sesuai dengan UUD 1945 secara bersyarat (conditionally constitutional), yaitu konstitusional sepanjang dimaknai "masa jabatan Jaksa Agung itu berakhir dengan berakhirnya masa jabatan Presiden Republik Indonesia dalam satu periode bersama-sama masa jabatan anggota kabinet atau diberhentikan dalam masa jabatannya oleh Presiden dalam periode yang bersangkutan". Penafsiran selain yang sudah ditetapkan mengakibatkan klausul hurufd tersebut tidak memiliki kekuatan hukum mengikat.

Ketentuan Putusan MK No. 49/PUU-VIII/2010 tentang Pengujian UndangUndang Nomor 16 Tahun 2004 tentang Kejaksaan RI, pada dasarnya telah memberikan jalan tengah terhadap permasalahan hukum penetapan jabatan Jaksa Agung Hendarman Supanji, tetapi apakah dengan demikian kedudukan hukum penetapan jabatan Jaksa Agung Hendarman Supanji menjadi tidak sah (tidak memiliki legalitas)?

\section{Rumusan Masalah}

Berdasarkan latar belakang permasalahan tersebut isu hukum dalam penelitian ini adalah: Pertama, bagaimanakah ketentuan-ketentuan hukum yang pernah berlaku mengatur mengenai penetapan masa jabatan jaksa agung? Kedua, bagaimanakah penetapan masa jabatan jaksa agung dalam sistem penetapan jabatan pejabat negara.

\section{Tujuan Penelitian}

Tujuan penelitian ini adalah Pertama, mengkaji ketentuan-ketentuan hukum yang pernah berlaku mengatur mengenai penetapan masa jabatan jaksa agung. Kedua, mengkaji bagaimanakah penetapan masa jabatan jaksa agung dalam sistem penetapan jabatan pejabat negara menurut UUD 1945. 


\section{Metode Penelitian}

Sesuai dengan latar belakang dan tujuannya, tipologi dalam penelitian ini adalah penelitian hukum normatif (dogmatic) ${ }^{6}$ yang ditujukan untuk menemukan dan merumuskan argumentasi hukum ${ }^{7}$, melalui analisis terhadap pokok permasalahan.

Pendekatan yang digunakan dalam penelitian ini meliputi: pertama, pendekatan historis (historical approach) yaitu dengan menelaah aturan hukum tentang penetapan jaksa agung yang pernah berlaku. Kedua, pendekatan perundang-undangan (statute approach), yaitu dengan menelaah aturan hukum yang berlaku terkait dengan kejaksaan agung. Ketiga, pendekatan perbandingan (comparative approach), yaitu dengan menelaah/membandingkan model-model penetapan pejabat negara.

Berdasarkan pendekatan yang telah dipilih, maka langkah penelitian yang dilakukan adalah menghimpun bahan-bahan hukum primer maupun sekunder yang berkaitan dengan permasalahan penelitian. Bahan hukum primer digunakan untuk menjelaskan isu hukum yang menjadi obyek pembahasan dengan bertitik tolak dari teori-teori, konsep dan asas-asas hukum yang menjadi dasar penelitian. Terhadap bahan hukum sekunder semuanya dicatat dengan menggunakan sistem kartu (card'system), yang disusun berdasarkan pokok permasalahan penelitian dan sistematika penulisan.

\section{Hasil dan Pembahasan}

\section{Pengertian Penetapan Masa Jabatan}

Penetapan atau beschikking menurut S. Prajudi Atmosudirdjo dirumuskan sebagai perbuatan hukum sepihak yang bersifat administrasi negara yang dilakukan oleh pejabat atau instansi penguasa (negara) yang berwenang dan berwajib khusus untuk itu. ${ }^{8}$ Syarat utama bagi suatu penetapan adalah, bahwa tindak hukum atau

${ }^{6}$ Menurut Philipus M. Hadjon mengutip pendapat DHM Meuwissen, bahwa dogmatik hukum atau ajaran hukum (de rechtsleer), merupakan ilmu hukum dalam arti sempit dari istilah rechtwetenschap yang tugasnya adalah deskripsi hukum positif, sistematisasi hukum positif dan dalam hal tertentu juga eksplanasi. Philipus M. Hadjon, "Pengkajian Ilmu Hukum Dogmatik", artikel dalam Jurnal Hukum Yuridika Nomor 6 Tahun IX, November-Desember 1994, hlm. 2

${ }^{7}$ Philipus M. Hadjon, “Revitalisasi Pendidikan Tinggi Hukum”, Makalah disampaikan dalam Seminar Nasional yang diselenggarakan oleh Senat Mahasiswa Fakultas Hukum Atma Jaya Yogyakarta, 12 Desember 1999, hlm. 7

${ }^{8}$ S. Prajudi Atmosudirdjo, Hukum Administrasi Negara, Ghalia Indonesia, Jakarta, 1994, hlm. 94 
perbuatan hukum (rechtschandeling) tersebut harus sepihak (eenzijdig) dan harus bersifat administrasi negara, artinya realisasi daripada suatu kehendak atau ketentuan undang-undang secara nyata kasual-individual. ${ }^{9}$

Semua penetapan yang diambil oleh administrasi negara dimuat atau dituangkan dalam suatu keputusan, dan pada umumnya keputusan dilakukan secara tertulis dan berbentuk surat keputusan atau sejenisnya. ${ }^{10}$ Misalnya Keputusan Tata Usaha Negara (KTUN) yaitu suatu penetapan tertulis yang dikeluarkan oleh badan atau Pejabat Tata Usaha Negara yang berisi Tindakan Hukum Tata Usaha Negara berdasarkan peraturan perundang-undangan yang berlaku, yang bersifat konkret, individual dan final, yang menimbulkan akibat hukum bagi seseorang atau badan hukum perdata. ${ }^{11}$ Contoh dari KTUN adalah Keputusan Presiden, Keputusan MPR dan lainnya.

Masa secara leksikologi berarti era, zaman, musim, tempo, atau saat. ${ }^{12}$ Sementara itu, jabatan berarti sekumpulan tugas dan tanggung jawab yang dibebankan oleh seorang pejabat yang berwenang kepada seseorang baik untuk waktu yang penuh maupun sebagian. Jabatan menunjukkan hal-hal yang dikerjakan, bukan orangnya. ${ }^{13}$ Dengan demikian masa jabatan dapat diartikan jangka waktu tertentu dalam melaksanakan tugas dan tanggungjawab yang diemban seorang pejabat. Istilah masa jabatan similar dengan masa bakti atau masa kerja.

\section{Penetapan Masa Jabatan Jaksa Agung Menurut Peraturan Perundang-undangan yang Berlaku}

Institusi Kejaksaan telah ada sejak masa sebelum Indonesia merdeka namun pasca kemerdekaan negara Republik Indonesia belum memiliki UU khusus yang mengatur Kejaksaan sehingga berdasarkan Pasal II Aturan Peralihan UUD 1945 digunakanlah indische staatsregeling, semacam undang-undang dasar negeri jajahan Hindia Belanda. ${ }^{14}$ Berdasarkan konstitusi ini kedudukan Kejaksaan Agung berdampingan dengan Mahkamah Agung yang secara administratif berada di bawah

${ }^{9}$ Ibid.

${ }^{10}$ Philipus M. Hadjon, dkk., Pengantar Hukum Administrasi Indonesia, Gadjah Mada University Press, Yogyakarta, 2000, hlm. 135

${ }^{11}$ Lihat Pasal 1 angka 3 Undang-Undang Nomor 5 Tahun 1986 tentang Peradilan Tata Usaha Negara

${ }^{12}$ Pius A. Partanto dan M. Dahlan Al Barry, Kamus Ilmiah Populer, Arkola, Surabaya, 2001, hlm. 441

${ }^{13}$ Patriata Westra (eds.), Ensiklopesi Administrasi, CV. Haji Masagung, Jakarta, 1989, hlm. 230

${ }^{14}$ http://yusril.ihzamahendra.com/2010/08/08/, diakses 2 Januari 2011 
Departemen Kehakiman, di bawah eksekutif, namun secara fungsional dalam menyelenggarakan peradilan bersifat independen. Sejak awal kedudukan Kejaksaan memang berdiri di dua sisi, yudisial dan eksekutif, sehingga menimbulkan kontradiksi dalam pengaturannya (dual obligation). ${ }^{15}$ Pola kelembangaan ini terus dipakai pada masa Konstitusi RIS (1949-1950), masa demokrasi parlementer (19501959) dan berakhir pada masa demokrasi terpimpin (1959-1965). Pada masa ini Kejaksaan yang awalnya berstatus lembaga nondepartemen di bawah Departemen Kehakiman menjadi lembaga yang berdiri sendiri, ${ }^{16}$ departemen tersendiri yang terpisah dari Departemen Kehakiman dan Mahkamah Agung, hingga saat ini.

Berdasarkan indische staatsregeling ini pula, Jaksa Agung adalah jabatan karir, bukan jabatan politik sehingga dalam praktiknya Jaksa Agung diangkat oleh Perdana Menteri atas usul Menteri Kehakiman. Pola ini kemudian berubah pada masa Konstitusi RIS, Jaksa Agung diangkat oleh Presiden atas usul Perdana Menteri, ${ }^{17}$ hingga timbulnya Dekrit Presiden 5 Juli 1959 yang disusul disahkannya UU No. 15 Tahun 1961.

Selama berada di bawah UUD 1945 pasca Dekrit Presiden 5 Juli 1959, dari ketiga undang-undang yang mengatur lembaga Kejaksaan yaitu UU No. 15 Tahun 1961, UU No. 5 Tahun 1991 dan UU No. 16 Tahun 2004 kesemuanya mengatur bahwa Kejaksaan adalah lembaga pemerintah yang berada di dalam ranah kekuasaan eksekutif. ${ }^{18}$ UU No. 15 Tahun 1961 menegaskan bahwa Kejaksaan ialah “alat negara”, UU No. 5 Tahun 1991 dan UU No. 16 Tahun 2004 menegaskan bahwa Kejaksaan adalah "lembaga pemerintah". Sementara itu ketiga UU tadi menetapkan Jaksa Agung adalah sebagai pembantu presiden karena diangkat dan diberhentikan oleh presiden dengan kedudukan setingkat menteri negara. ${ }^{19}$

Setelah akhir masa Orde Lama hingga berakirnya Orde Baru kewenangan mengangkat dan memberhentikan Jaksa Agung sepenuhnya menjadi kewenangan mutlak Presiden. Kemudian pada awal reformasi, demi independensi Kejaksaan dalam menjalankan tugasnya dari bayang-bayang kepentingan politik presiden, diusulkan untuk mengadopsikan pengaturan mengenai Kejaksaan dalam BAB IX tentang Kekuasaan Kehakiman dalam amandemen UUD 1945 namun gagal

${ }^{15}$ Riri Nazriyah, "Pemberhentian Jaksa Agung dan Hak Prerogatif Presiden,” Jurnal Konstitusi Vol. 7 No. 2 Oktober 2010, Sekretariat Jenderal dan Kepaniteraan Mahkamah Konstitusi, Jakarta, 2010, hlm. 30. Lihat juga Marwan Effendy, Kejaksaan RI Posisi dan Fungsinya dari Perspektif Hukum, Gramedia, Jakarta, 2005, hlm. 122

${ }^{16}$ Marwan Effendy, Kejaksaan ..., Ibid., hlm. 68

${ }^{17}$ http://yusril.ihzamahendra.com/2010/08/08/, diakses 2 Januari 2011

${ }^{18}$ Ibid.

${ }^{19}$ Marwan Effendy, Op. Cit., hlm. 9 
mencapai kesepakatan. Demikian pula ketika RUU Kejaksaan 2004 dibahas, terjadi ketidaksepakatan antara pemerintah dan DPR. Akhirnya Jaksa Agung tetap sebagai Pejabat Negara yang diangkat dan diberhentikan oleh presiden namun dalam menjalankan fungsinya Kejaksaan bersifat merdeka. ${ }^{20}$

Berikut dilakukan analisis terhadap penetapan masa jabatan Jaksa Agung berdasarkan undang-undang kejaksaan:

\section{Penetapan Masa Jabatan Jaksa Agung Menurut Undang-Undang Nomor 15 Tahun} 1961 tentang Ketentuan-ketentuan Pokok Kejaksaan (LN 1961 No. 254)

Undang-Undang Nomor 15 Tahun 1961 tentang Ketentuan-Ketentuan Pokok Kejaksaan (LN 1961 No. 254) memposisikan (kedudukan) kejaksaan sebagai alat negara penegak hukum yang terutama bertugas sebagai penuntut umum, bahkan dalam konteks penyelesaian revolusi, kejaksaan bukan saja "alat negara penegak hukum", tetapi kejaksaan adalah "alat revolusi" ${ }^{21}$

Penegasan kedudukan kejaksaan dalam Undang-Undang Nomor 15 Tahun 1961 mengandung dualitas makna bahwa jika dilihat dari penamaannya, sekalipun Kejaksaan sebagai alat penegak hukum bukan alat pemerintahan (eksekutif), namun jika dikaitkan dengan ketentuan Pasal 5 ayat (1) huruf a dan b UU ini bahwa penyelenggaraan tugas Departemen Kejaksaan dilakukan oleh Menteri dan Susunan organisasi Departemen Kejaksaan diatur dengan Keputusan Presiden, memperlihatkan bahwa posisi (kedudukan) Kejaksaan berada di bawah (di lingkungan) pemerintah (eksekutif/presiden). Departemen Kejaksaan dipimpin oleh seorang Menteri yang merupakan pembantu presiden, apalagi Departemen Kejaksaan ini diatur dalam suatu Keputusan Presiden.

Konsisten dengan pendirian bahwa institusi kejaksaan bukanlah bagian dari organ kekuasaan yudikatif, maka ketentuan Pasal 5 huruf a UU ini mengatakan “Penyelenggaraan tugas Departemen Kejaksaan dilakukan oleh Menteri”. Kalau Kejaksaan adalah sebuah departemen pemerintahan yang dipimpin Menteri, maka dengan sendirinya wewenang untuk mengangkat dan memberhentikan Jaksa Agung dalam sistem pemerintahan Presidensial22 adalah Presiden. Ketentuan ini,

${ }^{20}$ Jimly Asshiddiqie, Perkembangan dan Konsolidasi Lembaga Negara Pasca Reformasi, Sekretariat Jenderal dan Kepaniteraan MKRI, Jakarta, 2006, hlm. 222

${ }^{21}$ Yusril Ihza Mahendra, "Kedudukan Kejaksaan dan Posisi Jaksa Agung dalam Sistem Presidensial di Bawah UUD 1945”, http://www.dosen.narotama.ac.id, diakses 20 November 2011

${ }^{22}$ Tentang Pemerintahan Presidensiil dapat dibaca dalam tulisan R.M. Ananda B. Kusuma, "Sistem Pemerintahan Indonesia", artikel dalam Jurnal Konstitusi, Volume I, Nomr 1, Juli 2004 
sebenarnya hanyalah legitimasi atas apa yang telah dilakukan oleh Presiden dalam mengangkat Jaksa Agung sebagai menteri anggota kabinet dua tahun sebelumnya. Namun ketentuan ini, sekaligus menghapus ketentuan-ketentuan dalam Indische Staatsregeling, HIR dan RIB. Jaksa Agung tidak lagi diangkat oleh Menteri Kehakiman dengan persetujuan Perdana Menteri, tetapi langsung diangkat oleh Presiden.

\section{Penetapan Masa Jabatan Jaksa Agung Menurut Undang-Undang Nomor 5 Tahun 1991 tentang Kejaksaan Republik Indonesia (LN 1991/59; TLN No. 3451)}

Undang-Undang Nomor 5 Tahun 1991 tentang Kejaksaan Republik Indonesia (LN 1991/59; TLN No. 3451) diundangkan pada tanggal 22 Juli 1991. Pada salah satu pertimbangan hukumnya ditentukan, bahwa kedudukan dan peranan kejaksaan RI adalah sebagai lembaga pemerintahan yang melaksanakan kekuasaan negara di bidang penuntutan dalam tata susunan kekuasaan badan-badan penegak hukum dan keadilan.

Ketentuan Undang-Undang Nomor 5 Tahun 1991 ini telah melakukan pergeseran cukup penting dalam memandang kedudukan institusi Kejaksaan, dari "alat negara” menjadi “lembaga pemerintahan". Penegasan ini, lebih mempertajam dari rumusan UU No. 15 Tahun 1961, yang menempatkan Kejaksaan sepenuhnya berada dalam ranah eksekutif. Selanjutnya dikatakan bahwa Jaksa Agung adalah pimpinan dan penanggungjawab tertinggi kejaksaan yang mengendalikan pelaksanaan tugas dan wewenang kejaksaan" ${ }^{23}$. Istilah Departemen Kejaksaan dan Menteri sebagai penyelenggaranya sebagaimana diatur di dalam UU No. 15 Tahun 1961 dihapuskan.

Penetapan Jaksa Agung diatur dalam Pasal 19 yang menetapkan bahwa jaksa agung diangkat dan diberhentikan oleh serta bertanggungjawab kepada Presiden. ${ }^{24}$ Selanjutnya dalam Pasal 21 ayat (4) ditetapkan, bahwa wakil jaksa agung dan jaksa agung muda diberhentikan dengan hormat dari jabatannya karena: a. permintaan sendiri; atau b. sakit jasmani atau rohani terus menerus; atau c. telah berumur 60 (enam puluh) tahun; atau d. ternyata tidak cakap menjalankan tugas; atau e. meninggal dunia.

\footnotetext{
${ }^{23}$ Lihat Pasal 18 ayat (1) Undang-Undang Nomor 5 Tahun 1991 tentang Kejaksaan Republik Indonesia

${ }^{24}$ Penegasan bahwa pengangkatan dan pemberhentian Jaksa Agung adalah kewenangan Presiden, serta pertanggungjawabannya kepada Presiden, sekali lagi mempertegas bahwa kejaksaan adalah sepenuhnya berada di bawah ranah kekuasaan eksekutif. Penegasan ini adalah sejalan pula dengan konsideran mengingat yang digunakan dalam penyusunan undang-undang ini, yakni sebagaimana UU No 15 Tahun 1961 tidaklah menjadikan ketentuan Bab IX tentang Kekuasaan Kehakiman sebagai dasar pembentukannya. Undang-undang ini, selain menggunakan ketentuan Pasal 5 ayat (1) dan Pasal 20 ayat (1) UUD 1945, malah menjadikan UU No. 14 Tahun 1970 tentang Pokok-Pokok Kekuasaan Kehakiman dan UU No. 8 Tahun 1981 tentang Hukum Acara Pidana sebagai konsideran mengingatnya.
} 
Berdasarkan ketentuan Undang-Undang Nomor 5 Tahun 1991 tentang Kejaksaan Republik Indonesia, maka pada dasarkan tidak mengatur mengenai pemberhentian (masa jabatan) jaksa agung, hal ini tentunya berbeda dengan keberadaan wakil jaksa agung dan jaksa agung yang secara limitatif ditentukan masa jabatannya. Hal yang sama sebenarnya juga tidak ada di dalam hukum tatanegara Belanda dan ketentuanketentuan di dalam HIR dan RIB, karena jaksa agung adalah jaksa karier yang akan pensiun pada usia tertentu, atau setiap saat dia dapat diberhentikan oleh Menteri Kehakiman dengan persetujuan Perdana Menteri. Dalam UU No. 5 Tahun 1991 tidak ada pula pembatasan apakah jaksa agung diangkat dari jaksa karier, ataukah pengangkatan itu bersifat politik.Kedua-duanya dapat dilakukan oleh Presiden, berdasarkan pertimbangan subyektif Presiden sendiri.

Merujuk pada konvensi ketatenegaraan yang telah berlangsung sejak 1971, yakni jaksa agung selalu diangkat dan diberhentikan Presiden pada awal dan akhir masa bakti kabinet terus berlangsung. Konvensi itu terus diikuti sesudah Presiden Soeharto menyatakan berhenti dari jabatannya sebagai Presiden pada tanggal 21 Maret 1998. Pengangkatan dan pemberhentian jaksa agung di awal dan diakhir masa bakti kabinet, diikuti juga selama UU No. 5 Tahun 1991 ini berlaku, yakni di bawah Presiden B.J. Habibie, Abdurrahman Wahid dan Megawati Sukarnoputri. Konvensi adalah hukum dasar yang tidak tertulis, namun terpelihara dalam praktik penyelenggaraan negara.

\section{Penetapan Masa Jabatan Jaksa Agung Menurut Undang-Undang Nomor 16 Tahun} 2004 tentang Kejaksaan Republik Indonesia (LN 2004/67, TLN No. 4401)

Undang-Undang Nomor 16 Tahun 2004 tentang Kejaksaan RI, merupakan UU yang sekarang berlaku. Berdasarkan Pasal 2 ayat (1) UU No.16 Tahun 2004, ditentukan bahwa kedudukan Kejaksaan adalah: (a) sebagai lembaga pemerintah (eksekutif), (b) sebagai pelaksana kekuasaan negara di bidang penuntutan, dan (c) sebagai pelaksana kewenangan lain berdasarkan undang-undang. ${ }^{25}$ Selanjutnya Pasal 2 ayat (2), menegaskan bahwa kekuasaan (kewenangan) penuntutan dan kewenangan lain itu dilaksanakan secara merdeka. Artinya dalam melaksanakan fungsi, tugas, dan wewenangnya terlepas dari pengaruh kekuasaan pemerintah dan pengaruh kekuasaan lainnya. ${ }^{26}$

\footnotetext{
${ }^{25}$ Marwan Effendy, Kejaksaan RI..., Op.Cit., hlm. 122

${ }^{26}$ Penjelasan Pasal 2 ayat (2) UU No.16 Tahun 2004 tentang Kejaksaan RI
} 
Pasal 2 ayat (3) UU ini menyatakan bahwa Kejaksaan adalah satu dan tidak terpisahkan. Artinya Kejaksaan memiliki satu landasan dalam pelaksanaan tugas dan wewenangnya di bidang penuntutan yang bertujuan memelihara kesatuan kebijakan di bidang penuntutan sehingga dapat menampilkan ciri khas yang menyatu dalam tata pikir, tata laku, dan tata kerja Kejaksaan. Oleh karena itu kegiatan penuntutan di pengadilan oleh Kejaksaan tidak akan berhenti hanya karena jaksa yang semula bertugas berhalangan. Dalam hal demikian tugas penuntutan oleh Kejaksaan akan tetap berlangsung sekalipun untuk itu dilakukan oleh jaksa lainnya sebagai pengganti. ${ }^{27}$

Kejaksaan sebagai lembaga pemerintah terdiri atas Kejaksaan Agung, Kejaksaan Tinggi dan Kejaksaan Negeri. Kejaksaan Agung berkedudukan di ibu kota negara dan daerah hukumnya meliputi seluruh wilayah kekuasaan Negara Republik Indonesia.

Berkaitan dengan penetapan masa jabatan Jaksa Agung diatur dalam Pasal 22 ayat (1) UU No. 16 Tahun 2004 tentang Kejaksaan RI yang menegaskan: Jaksa Agung diberhentikan dengan hormat dari jabatannya karena:
a. meninggal dunia;
b. permintaan sendiri;
c. sakit jasmani atau rohani terus-menerus;
d.berakhir masa jabatannya;
e. tidak lagi memenuhi salah satu syarat sebagaimana dimaksud dalam Pasal 21.

Berdasarkan perundang-undangan yang pernah ada mulai Undang-Undang Nomor 15 Tahun 1961, Undang-Undang Nomor 5 Tahun 1991 dan Undang-Undang Nomor 16 Tahun 2004 pada dasarnya tidak ada yang mengatur secara definitif dan limitatif berapa lama seorang jaksa agung menduduki jabatannya.

\section{Penetapan Masa Jabatan Jaksa Agung RI Berdasarkan Putusan Mahkamah Konstitusi Nomor 49/PUU-VIII/2010 tentang Pengujian Undang-Undang Nomor 16 Tahun 2004 Tentang Kejaksaan RI}

Pasal 22 ayat (1) huruf d UU No. 16 Tahun 2004 tentang Kejaksaan menegaskan sebagai berikut: Jaksa Agung diberhentikan dengan hormat dari jabatannya karena:
a............................

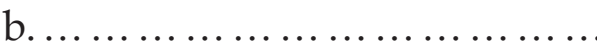
c. ..........................
d.berakhir masa jabatannya;
e. 
Tidak ada penjelasan secara limitatif dari ketentuan Pasal 22 ayat (1) huruf d UU No. 16 Tahun 2004 tentang Kejaksaan. Artinya, kapankah berakhirnya masa jabatan jaksa agung tersebut tidak ditentukan secara pasti. Menurut Yusril Ihza Mahendra klausul huruf d tersebut tidak jelas sehingga multitafsir (polyinterpretabel) karena tidak menjelaskan dengan pasti kapan seorang jaksa agung dianggap berakhir masa jabatannya. Klausul itu dapat saja ditafsirkan seumur hidup ${ }^{28}$ selama tidak diberhentikan dan sebagainya. Hal ini dapat menimbulkan ketidakpastian hukum (rechsonzekerheid). Selaku warga negara Yusril merasa dirugikan akibat ketentuan Pasal 22 ayat (1) huruf d UU No. 16 Tahun 2004 tentang Kejaksaan sehingga Yusril mengajukan permohon agar MK sebagai the guardian of constitution dan the final interpreter of the constitution memberikan tafsir yang pasti.

Erman Rajagukguk, Margarito Kamis dan Andi Muhammad Asrun yang ditunjuk sebagai saksi ahli dalam persidangan judicil review Pasal 22 ayat (1) huruf d UUK 2004 berpendapat bahwa pada dasarnya jaksa agung sebagai pejabat negara setingkat menteri ataupun sebagai anggota kabinet berakhir bersamaan dengan berakhirnya masa jabatan anggota kabinet lainnya. ${ }^{29}$

Bagir Manan berpendapat jaksa agung sebagai jaksa berakhir masa jabatannya karena memasuki usia pensiun. Sementara jaksa agung sebagai pejabat setingkat menteri negara dan anggota kabinet, maka jabatannya itu berakhir bersama-sama dengan anggota kabinet yang lain. Merujuk kepada Keppres Nomor 187/M Tahun 2004 dan Keppres Nomor 31/P Tahun 2007, maka jabatan Hendarman Supandji telah berakhir pada tanggal 20 Oktober 2009. Sejak itu dia menduduki jabatan itu secara tidak sah. Segala tindakan yang dilakukan oleh pejabat yang tidak sah, tidaklah membawa akibat hukum. ${ }^{30}$

Selanjutnya menurut Laica Marzuki bahwa jaksa agung adalah publieke ambt atau jabatan publik. Mengutip Logemann, jabatan adalah person pribadi hukum yang bersifat abstrak yang tidak dapat menjalankan fungsi dan kewenangannya. Karena itu harus diwakili oleh pemegang jabatan atau ambtsdrager. Jabatan bersifat langgeng dan abadi, sementara pemegang jabatan atau ambtsdrager datang dan pergi

${ }^{28}$ Menurut kesaksian Denny Indrayana dan Achmad Roestandi, sebagai salah satu saksi ahli dari pihak pemerintah, dalam persidangan uji materi UU No. 16 Tahun 2004. Lihat putusan MK No.49/PUU-VII/2010

${ }^{29}$ Pendapat Erman Rajagukguk, Margarito Kamis dan Andi Muhammad Asrun ini disampaikan pada saat mereka menjadi saksi ahli dari pihak pemohon pada persidangan uji materi UU No. 16 Tahun 2004

${ }^{30}$ Pendapat Bagir Manan yang disampaikan pada saat mereka menjadi saksi ahli dari pihah pemohon pada persidangan uji materi UU No. 16 Tahun 2004 
silih berganti. Masa jabatan Hendarman Supandji berdasarkan Keppres Nomor 187/ M Tahun 2004 berakhir pada tanggal 20 Oktober 2009. Namun sejak itu tidak pernah diangkat kembali, baik sebagai jaksa agung yang menjadi anggota kabinet maupun di luar kabinet. Dengan demikian, Hendarman telah mewakili jabatan het ambt Jaksa Agung secara terus-menerus dengan masa jabatan yang tidak kunjung berakhir. Ini semua akibat multitafsir ketentuan Pasal 22 ayat (1) huruf d UU Kejaksaan, yang mencederai asas kedaulatan rakyat dan asas kepastian hukum di dalam UUD $1945 .{ }^{31}$

H.A.S. Natabaya berpendapat, ketentuan Pasal 22 ayat (1) huruf d UU Nomor 16 Tahun 2004 bertentangan dengan asas beginselen van behoorlijk regelgeving atau asas pembentukan perundang-undangan yang baik, sebagaimana juga diatur dalam Pasal 6 UU Nomor 10 Tahun 2004 tentang Pembentukan Peraturan Perundang-Undangan. Ketentuan ini tidak memenuhi syarat adanya kepastian hukum. ${ }^{32}$

Berbeda dengan pendapat tersebut di atas, M. Fadjrul Falakh berpendapat UU No. 16 Tahun 2004 memang tidak mengatur masa jabatan jaksa agung sebagai pejabat negara. Jabatan jaksa agung tidak dapat dikaitkan dengan masa jabatan sebagai anggota kabinet, karena jaksa agung tidak boleh merangkap pejabat negara yang lain, termasuk merangkap jabatan menjadi menteri. Jabatan jaksa agung termasuk jabatan publik sehingga mengenai pengangkatan dan pemberhentiannya bergantung kepada keputusan politik dari pejabat yang berwenang (Presiden). Menurut kaidah TUN, tindakan tidak menerbitkan surat keputusan tentang sesuatu harus diartikan bahwa pejabat TUN tersebut telah memutus sesuai tindakan yang tidak dituangkan dalam suatu surat atau dokumen tertulis. Hal tersebut merupakan presumption of legality. ${ }^{33}$

Pendapat M. Fadjrul Falakh mendapat dukungan dari beberapa ahli hukum antara lain Philipus Hadjon, Andan Buyung Nasution dan Denny Indrayana selaku saksi ahli dari pihak pemerintah.

MK dalam pertimbangan hukumnya menerima pendapat saksi ahli, HAS Natabaya, bahwa UUK 2004 tidak memenuhi asas-asas umum pembentukan

\footnotetext{
${ }^{31}$ Pendapat Laica Marzuki yang disampaikan pada saat mereka menjadi saksi ahli dari pihak pemohon pada persidangan uji materi UU No. 16 Tahun 2004

${ }^{32}$ Pendapat H.A.S. Natabaya yang disampaikan pada saat mereka menjadi saksi ahli dari pihak pemohon pada persidangan uji materi UU No. 16 Tahun 2004

33 Pendapat H.A.S. Natabaya yang disampaikan pada saat mereka menjadi saksi ahli dari pihak termohon (Pemerintah) pada persidangan uji materi UU No. 16 Tahun 2004
} 
perundang-undangan yang baik (algemene beginselen van behoorlijke regelgeving) yang sejalan dengan asas-asas umum penyelenggaraan pemerintahan yang baik (algemene beginselen van behoorlijke bestuur, the general principle of good administration), ${ }^{34}$ karena adanya inkonsistensi antara Pasal 19 UUK 2004 dan Pasal 22 ayat (1) huruf d. Pendapat MK menyatakan bahwa:

Jaksa Agung sebagai Pejabat Negara seharusnya diberhentikan dengan hormat dari jabatannya oleh Presiden berdasarkan kondisi yang pasti, yaitu, jika ia meninggal dunia, atas permintaan sendiri, atau karena sakit jasmani dan rohani terus menerus, namun demikian tentang kapan "berakhir masa jabatannya" merupakan kondisi yang tidak menentu. ${ }^{35}$

Oleh karena itu pokok masalahnya adalah pada proses pembentukan UU $a$ quo. MK berpendapat:

...permasalahan penafsiran terhadap Pasal 22 ayat (1) huruf d UU 16/2004 yang menyatakan "Jaksa Agung diberhentikan dengan hormat dari jabatannya karena:... d. berakhir masa jabatannya" bukanlah masalah konstitusionalitas norma yang merupakan lingkup ranah judicial review yang menjadi wewenang Mahkamah, tetapi lebih merupakan lingkup ranah legislative review yang menjadi wewenang pembentuk undang-undang, yaitu DPR dan Presiden. Akan tetapi masalah konstitusionalitas timbul ketika frasa ini bersifat multitafsir sehingga menimbulkan ketidakpastian hukum, termasuk ketidakpastian hukum dalam hal kedudukan di hadapan hukum.

Artinya MK menyatakan tetap berwenang mengadili perkara ini. Selanjutnya menurut MK paling tidak ada empat alternatif untuk menentukan kapan mulai diangkat dan saat berhentinya pejabat negara menduduki jabatannya in casu Jaksa Agung, yaitu: (a) berdasar periodesasi Kabinet dan/atau periode masa jabatan Presiden yang mengangkatnya, (b) berdasar periode (masa waktu tertentu) yang fixed tanpa dikaitkan dengan jabatan politik di kabinet, (c) berdasarkan usia atau batas umur pensiun, (d) berdasarkan diskresi Presiden/pejabat yang mengangkatnya.

Terkait hal ini MK menyatakan: Oleh karena ternyata tidak ada satu pun dari alternatif tersebut yang secara tegas dianut dalam UU a quo, maka menurut Mahkamah, ketentuan "karena berakhir masa jabatannya" itu memang menimbulkan ketidakpastian hukum. Mahkamah berpendapat pula bahwa karena ketidakpastian hukum itu bertentangan dengan konstitusi maka seharusnya pembentuk Undang-Undang segera melakukan legislative review untuk memberi kepastian dengan memilih salah satu dari alternatif-alternatif tersebut. Namun

\footnotetext{
${ }^{34}$ Putusan MK No. 49/PUU-VIII/2010, hlm. 130

${ }^{35}$ Ibid.
} 
karena legislative review memerlukan prosedur dan waktu yang relatif lama, maka sambil menunggu langkah tersebut Mahkamah memberikan penafsiran sebagai syarat konstitusional (conditionally constitutional) untuk berlakunya Pasal 22 ayat (1) hurufd UU 16/2004 tersebut yang dinyatakan berlaku prospektif sejak selesai diucapkannya putusan ini. ${ }^{36}$

MK juga menyatakan “... dalam praktik ketatanegaraan yang berlangsung selama ini, penetapan masa jabatan secara tegas telah digunakan dalam beberapa jabatan publik. ...". Peraturan yang tegas tersebut dapat ditemukan misalnya pada Pasal 7 UUD 1945, Undang-Undang KY, KPK, MK dan MA.

Mempertimbangkan semua bukti-bukti persidangan dan keterangan-keterangan saksi ahli akhirnya dalam amar putusan MK menyatakan Pasal 22 ayat (1) huruf d UU No. 16 Tahun 2004 tentang Kejaksaan RI adalah sesuai dengan UUD 1945, oleh karena itu mempunyai kekuatan hukum mengikat, secara bersyarat (conditionally constitutional), yaitu konstitusional sepanjang dimaknai “masa jabatan Jaksa Agung itu berakhir dengan berakhirnya masa jabatan Presiden Republik Indonesia dalam satu periode bersama-sama masa jabatan anggota kabinet atau diberhentikan dalam masa jabatannya oleh Presiden dalam periode yang bersangkutan" ${ }^{\prime 3}$, artinya Jaksa agung dapat diberhentikan sewaktu-waktu dalam masa tugas oleh presiden.

\section{Penetapan Masa Jabatan Jaksa Agung dalam Sistem Penetapan Jabatan Pejabat Negara}

Istilah Pejabat Negara berdasarkan Undang-Undang Nomor 28 Tahun 1999 tentang Penyelenggaraan Negara Yang Bersih dan Bebas dari Korupsi, Kolusi dan Nepotisme Bab I Ketentuan Umum Pasal 1 angka 1, dinyatakan Penyelengara Negara adalah pejabat negara yang menjalankan fungsi eksekutif, legislatif, atau yudisial...". Selanjutnya Pasal 2 menyatakan, bahwa "Penyelenggara Negara meliputi: 1. Pejabat Negara pada Lembaga Tertinggi Negara; ${ }^{38}$ 2. Pejabat Negara pada Lembaga Tinggi Negara; 3. Menteri; 4. Gubernur; 5. Hakim; 6. Pejabat Negara lain... "; 7. Pejabat lain... .

Berdasarkan uraian tersebut dapatlah disimpulkan bahwa yang dimaksud dengan Pejabat Negara adalah: (1) Pejabat yang duduk pada Lembaga Tinggi Negara

\footnotetext{
${ }^{36}$ Ibid., hlm. 133

${ }^{37}$ Putusan MK No. 49/PUU-VIII/2010, hlm. 134

${ }^{38}$ Setelah perubahan UUD 1945 dalam ketatanegaraan dan sistem pemerintahan di Indonesia tidak dikenal lagi Lembaga Tertinggi Negara.
} 
yang setelah amandemen UUD 1945 meliputi: (a) lembaga eksekutif yaitu Presiden dan Wakil Presiden; (b) lembaga legislatif MPR, DPR, DPD; (c) lembaga yudisial yaitu: MA, MK, KY, dan (d) lembaga eksaminatif BPK; (2) Menteri, Gubernur dan Hakim. (3) Pejabat Negara lain menurut ketentuan perundang-undangan misalnya Kepala Perwakilan RI di luar negeri yang berkedudukan sebagai Duta Besar Luar Biasa dan Berkuasa Penuh, Wakil Gubenur dan Bupati/Wali Kota. (4) Pejabat lain seperti Direksi BUMN, BUMD, Pimpinan BI, Pimpinan PTN, Pejabat Eselon I, Jaksa, Penyidik, Panitera \& Pemimpin/Bendaharawan Proyek.

Pejabat negara adalah pimpinan dan anggota lembaga tertinggi/tinggi negara sebagaimana dimaksud dalam Undang-Undang Dasar 1945 dan Pejabat Negara lainnya yang ditentukan oleh Undang-undang. Pejabat Negara terdiri atas: a. Presiden dan Wakil Presiden; b. Ketua, Wakil Ketua, dan Anggota Majelis Permusyawaratan Rakyat; c. Ketua, Wakil Ketua, dan Anggota Dewan Perwakilan Rakyat; d. Ketua, Wakil Ketua, Ketua Muda, dan Hakim Agung pada Mahkamah Agung, serta Ketua, Wakil Ketua dan Hakim pada pada semua Badan Peradilan; e. Ketua, Wakil Ketua, dan Anggota Dewan Pertimbangan Agung; f. Ketua, Wakil Ketua, dan Anggota Badan Pemeriksa Keuangan; g. Menteri dan jabatan yang setingkat menteri; h. Kepala Perwakilan Republik Indonesia di luar negeri yang berkedudukan sebagai Duta Besar Luar Biasa dan Berkuasa Penuh; i. Gubernur dan Wakil Gubernur; j. Bupati/ Walikota dan Wakil Bupati/Wakil Walikota.

Dalam Undang-Undang Nomor 8 Tahun 1974 tentang Pokok-Pokok Kepegawaian dikenal 2 (dua) jenis jabatan yakni jabatan negara dan jabatan negeri. Menurut Badan Administrasi Kepegawaian Negara, untuk menghadapi dinamika perkembangan politik dan pemerintahan, perlu adanya perluasan jabatan negara serta tambahan jabatan pada lembaga swadana dan perusahaan milik negara (lembaga pendidikan tinggi, lembaga pelayanan kesehatan, lembaga litbang, lembaga diklat, badan otorita, serta badan usaha milik negara). ${ }^{39}$ Undang-Undang Nomor 43 tahun 1999 tentang Perubahan Atas Undang-Undang Nomor 8 Tahun 1974 tentang Pokok-Pokok Kepegawaian, melakukan reformasi terhadap penyelenggaraan pelayananan publik, dengan melakukan pembaharuan dalam struktur kepegawaian negara dengan menetapkan adanya tiga jenis jabatan pada

${ }^{39}$ Badan Administrasi Kepegawaian Negara, "Kebijakan Kepegawaian Negara dalam Rangka Penyelenggaraan Pemerintahan Pasca Pemilu 1999”, Bahan Presentasi pada Rakernas Depdikbud, 17 Mei 1999 di Jakarta, 17 Mei 1999 , hlm. 7 
kepegawaian negara yakni: jabatan negara, jabatan negeri dan jabatan pada lembaga swadana dan perusahaan milik negara.

Berbeda dengan Undang-Undang Nomor 28 Tahun 1999 tentang Penyelenggaraan Negara Yang Bersih dan Bebas dari Korupsi, Kolusi dan Nepotisme maupun Undang-Undang Nomor 43 Tahun 1999 tentang Perubahan Atas Undang-Undang Nomor 8 Tahun 1974 tentang Pokok-Pokok Kepegawaian, dalam Undang-Undang Nomor 14 Tahun 2008 tentang Keterbukaan Informasi Publik, digunakan istilah pejabat publik untuk menunjuk pejabat negara. Pasal 1 Angka 8 Undang-Undang Nomor 14 Tahun 2008 tentang Keterbukaan Informasi Publik, menyatakan pejabat publik adalah orang yang ditunjuk dan diberi tugas untuk menduduki posisi atau jabatan tertentu pada badan publik. ${ }^{40}$ Sementara Badan Publik adalah lembaga eksekutif, legislatif, yudikatif, dan badan lain yang fungsi dan tugas pokoknya berkaitan dengan penyelenggaraan negara, yang sebagian atau seluruh dananya bersumber dari APBN dan/atau APBD, atau organisasi nonpemerintah sepanjang sebagian atau seluruh dananya bersumber dari APBN dan/atau APBD, sumbangan masyarakat, dan/atau luar negeri. ${ }^{41}$ Dalam Hukum Tata Negara dan Hukum Administrasi Negara istilah "Pejabat Publik" memiliki makna yang similar dengan istilah "Pejabat Tata Usaha Negara"42.

Dalam praktik ketatanegaraan Negara Republik Indonesia terdapat aturanaturan yang tegas mengenai sistem penetapan masa jabatan pejabat publik. Berikut disajikan beberapa sistem pengaturan penetapan masa jabatan pejabat publik.

\section{Masa Jabatan Presiden dan Wakil Presiden}

Masa jabatan Presiden dan Wakil Presiden, diatur dalam Pasal 7 UUDNRI 1945 yang menegaskan bahwa Presiden dan Wakil Presiden memegang jabatan selama lima tahun dan sesudahnya dapat dipilih kembali dalam jabatan yang sama, hanya untuk satu kali masa jabatan.

Penetapan masa jabatan presiden selama 5 (lima) tahun ini juga berlaku bagi kebanyakan negara-negara Eropa atau negara-negara di dunia yang menganut sistem hukum Eropa Kontinental (civil law), sementara bagi kebanyakan penganut sistem

\footnotetext{
${ }^{40}$ Lihat Pasal 1 Angka 8 Undang-Undang Nomor 14 Tahun 2008 tentang Keterbukaan Informasi Publik

${ }^{41}$ Pasal 1 angka 3 Undang-Undang Nomor 14 Tahun 2008 tentang Keterbukaan Informasi Publik

${ }^{42}$ Lihat Pasal 1 Angka 1 Undang-Undang Nomor 5 Tahun 1986 junto Undang-Undang Nomor 9 Tahun 2004 tentang Peradilan Tata Usaha Negara
} 
Anglo Saxon (common law) seperti Amerika Serikat, ${ }^{43}$ Australia, Inggris dan negaranegara persemakmuran Inggris (Malaysia, Philipina dan lainnya) menetapkan masa jabatan untuk presiden selama 4 (empat) tahun.

\section{Penetapan Masa Jabatan Anggota Komisi Yudisial}

Masa jabatan anggota Komisi Yudisial, diatur dalam Pasal 29 Undang-Undang Nomor 22 Tahun 2004 tentang Komisi Yudisial (LN 2004 No. 89, TLN No. 4415) yang menegaskan bahwa anggota Komisi Yudisial memegang jabatan selama masa 5 (lima) tahun dan sesudahnya dapat dipilih kembali untuk 1 (satu) kali masa jabatan. Penetapan masa jabatan ini bebeda-beda untuk setiap negara yang konstitusinya mengadopsi lembaga Komisi Yudisial atau sejenisnya. Di Eropa Selatan sebagaimana hasil penelitian Wim Voermans, Perancis menetapkan masa jabatan anggota KY (Conseil superieur de la magistrature/CSM) selama 4 tahun, dan Spanyol menetapkan masa jabatan anggota KY (El Consejo General del Poder Judicial) untuk kurun waktu 5 (lima) tahun, ${ }^{44}$ dan Italia menetapkan masa jabatan anggota KY (Consiglio Superiore della Magistratura) kecuali anggota tetap yaitu Presiden, Ketua MA dan Jaksa Agung diangkat untuk masa 4 (empat) tahun. ${ }^{45}$ Sementara negara-negara Eropa Utara ratarata menetapkan masa jabatan anggota KY, seperti KY di Denmark (Domstolsstyrelsen) untuk kurun waktu 4 (empat) tahun. ${ }^{46}$

\section{Penetapan Masa Jabatan Hakim Konstitusi}

Masa jabatan hakim konstitusi, diatur dalam Pasal 22 dan Pasal 23 ayat (1) huruf c dan huruf d Undang-Undang Nomor 24 Tahun 2003 tentang Mahkamah Konstitusi (LN 2003 No. 98, TLN No. 4316) yang menyatakan bahwa masa jabatan hakim konstitusi selama 5 (lima) tahun dan dapat dipilih kembali hanya untuk 1 (satu) kali masa jabatan berikutnya atau masa jabatan tersebut berakhir karena memasuki usia pensiun, yaitu 67 tahun.

\footnotetext{
${ }^{43}$ Pasal I ayat (1) Bagian II UUD Amerika Serikat menyatakan, Kekuasaan Eksekutifberada dalam tangan Presiden dari Amerika Serikat. Ia memangku jabatannya selama masa empat tabun dan bersama-sama dengan Wakil Presiden, dipilih untuk. masa jabatan yang sama ....

${ }^{44}$ Wim Voermans, Raden voor de Rechtpraak in landen van de Europese Unie, Terj., Adi Nugroho dan M. Zaki Hussein, LeIP, Jakarta, 2002, hlm. 12

${ }^{45}$ Ibid., hlm. 91-92

${ }^{46}$ Ibid., hlm. 56
} 
Penetapan masa jabatan hakim konstitusi ini berbeda-beda bagi beberapa negara yang dalam konstitusinya mengadopsi lembaga Mahkamah Konstitusi dalam sistem ketatanegaraan. Republik Federal Jerman menetapkan masa jabatan hakim konstitusi pada lembaga Mahkamah Konstitusi (ver) selama 12 tahun dan setelahnya tidak dapat dipilih kembali, ${ }^{47}$ Perancis menetapan masa jabatan hakim konstitusi pada Dewan Konstitusi selama 9 tahun dan setelahnya tidak dapat dipilih kembali. ${ }^{48}$ Sementara Afrika Selatan masa jabatan hakim ditetapkan 12 tahun dan memasuki usia purna bhakti jika mencapai usia 70 tahun. ${ }^{49}$ Korea Selatan menetapkan masa jabatan hakim konstitusi selama 9 tahun dan setelah itu tidak dapat dipilih kembali ${ }^{50}$ dan memasuki usia pensiun pada usia 70 tahun bagi hakim Ketua (Ketua MK) dan 65 tahun bagi hakim anggota. ${ }^{51}$

\section{Penetapan Masa Jabatan Hakim Agung}

Masa jabatan hakim agung, diatur dalam Pasal 11 huruf b Undang-Undang Nomor 3 Tahun 2009 tentang Perubahan Kedua Undang-Undang Nomor 14 Tahun 1985 tentang Mahkamah Agung (LN 2009 No. 3, TLN. 4958) yang mengatur bahwa masa jabatan hakim agung ditentukan sampai usia pensiun, yaitu 70 tahun. ${ }^{52}$ Di Jerman ditentukan hakim dan hakim agung diangkat untuk masa jabatan seumur hidup, tetapi undang-undang juga dapat menetapkan masa batas pensiun bagi hakim yang diangkat seumur hidup tersebut. ${ }^{53}$

\section{Penutup}

Perundang-undangan yang pernah ada mulai indische staatsregeling (UUD Hindia Belanda), UU No. 15 Tahun 1961, UU No. 5 Tahun 1991 hingga UU No. 16 Tahun

${ }^{47}$ Jimly Asshiddiqie dan Ahmad Syahrizal, Peradilan Konstitusi di Sepuluh Negara, Jakarta: Setjen dan Kepanietraan MKRI, hlm. 47

${ }^{48}$ Lihat Title 7 The Conceil Constitutionnel, Article 56, The Constitution of 1958, (Lihat Pasal 56 Konstitusi Republik Kelima Perancis 1958)

${ }^{49}$ Lihat Pasal 176 Konstitusi Afrika Selatan

${ }^{50}$ Lihat Pasal 111 ayat (1), (2) dan (3) Konstitusi Korea Selatan

${ }^{51}$ Hon Ha Kyung-chull, "The Constitutional Court System of Korea, The Short History of 15 year-old Challenge", In Firts Regional Seminar of Asian Constitutional Court Judges: Present Status and Future Development of Constitutional Jurisdiction in Asia, Hotel Intercontinental Midplaza, Jakarta September 8, 2003, Jakarta: Mahkamah Konstitusi RI and Konrad Adenauer Stiftung.

${ }^{52}$ Putusan MK No. 49/PUU-VIII/2010, hlm. 28

${ }^{53}$ Lihat Pasal 97 Konstitusi Republik Federal Jerman 
2004 tidak ada yang mengatur secara definitif maupun limitatif berapa lama seorang jaksa agung menduduki jabatannya. Namun setelah pemilu 1971 Presiden Soeharto memulai sebuah konvensi ketatanegaraan, yakni jaksa agung yang selalu diangkat di awal kabinet dan berakhir masa jabatannya dengan berakhirnya masa bakti kabinet itu. Dengan kata lain masa jabatan jaksa agung adalah 5 (lima) tahun.

MK dalam Amar Putusan MK No. 49/PUU-VIII/ 2010 tentang Pengujian Pasal 22 ayat (1) huruf d UU No. 16 Tahun 2004 tentang Kejaksaan RI meskipun dengan amar putusan konstitusional bersyarat (conditionally constitutional) jelas MK lebih mengacu pada fakta konvensi ketetanegaraan ini. Artinya masa jabatan Jaksa Agung sebagai pejabat negara setingkat menteri negara yang menjadi anggota kabinet sebagai pembantu Presiden adalah tetap 5 (lima) tahun, terlepas nanti jika RUU kejaksaan yang baru yang sedang digodok oleh pembentuk UU, DPR bersama Presiden, saat ini menentukan lain. Karena memang penetapan masa jabatan pejabat publik yang tertuang dalam undang-undang adalah sepenuhnya menjadi kebijakan legislasi yang dijalankan oleh DPR bersama Presiden.

Dalam praktik ketatanegaraan negara Republik Indonesia terdapat aturan-aturan yang tegas mengenai sistem penetapan masa jabatan pejabat publik, seperti Presiden ditetapkan masa jabatannya selama 5 (lima) tahun dan hanya dapat dipilih kembali untuk satu periode setelahnya, masa jabatan anggota Komisi Yudisial selama masa 5 (lima) tahun dan sesudahnya dapat dipilih kembali untuk 1 (satu) kali masa jabatan, masa jabatan hakim konstitusi selama 5 (lima) tahun dan dapat dipilih kembali hanya untuk 1 (satu) kali masa jabatan berikutnya atau masa jabatan tersebut berakhir karena memasuki usia pensiun 67 tahun dan masa jabatan hakim agung ditentukan sampai usia pensiun 70 tahun.

Berdasaran kenyataan demikian, dalam rangka memberikan kepastian hukum maka seharusnya penetapan masa jabatan pejabat publik seperti juga penetapan masa jabatan jaksa agung selayaknya ditentukan secara definitif dan limitatif sebagaimana penetapan masa jabatan pejabat publik lainnya seperti pejabat negara lainnya.

\section{Daftar Pustaka}

A Partanto, Pius, dan M. Dahlan Al Barry, 2001, Kamus Ilmiah Populer, Arkola, Surabaya 
Asshiddiqie, Jimly, "Struktur Ketatanegaraan Indonesia Setelah Perubahan Keempat UUD Tahun 1945", Makalah Disampaikan Pada Seminar Pembangunan Hukum Nasional VIII Tema Penegakan Hukum Dalam Era Pembangunan Berkelanjutan, Diselenggarakan oleh Badan Pembinaan Hukum Nasional Departemen Kehakiman dan Hak Asasi Manusia RI Denpasar, 14-18 Juli 2003

- Perkembangan dan Konsolidasi Lembaga Negara Pasca Reformasi, Sekretariat Jenderal dan Kepaniteraan MKRI, Jakarta, 2006.

dan Ahmad Syahrizal, Peradilan Konstitusi di Sepuluh Negara, Setjen dan Kepaniteraan MKRI, Jakarta, 2009.

Badan Administrasi Kepegawaian Negara, “Kebijakan Kepegawaian Negara dalam Rangka Penyelenggaraan Pemerintahan Pasca Pemilu 1999", Bahan Presentasi pada Rakernas Depdikbud, 17 Mei 1999 di Jakarta, 1999.

Effendy, Marwan, Kejaksaan RI Posisi dan Fungsinya dari Perspektif Hukum, Gramedia, Jakarta, 2005.

Ha Kyung-chull, Hon, “The Constitutional Court System of Korea, The Short History of 15 year-old Challenge", In Firts Regional Seminar of Asian Constitutional Court Judges: Present Status and Future Development of Constitutional Jurisdiction in Asia, Hotel Intercontinental Midplaza, Jakarta September 8, 2003, Mahkamah Konstitusi RI and Konrad Adenauer Stiftung, Jakarta

Ihza Mahendra, Yusril, “Kedudukan Kejaksaan dan Posisi Jaksa Agung dalam Sistem Presidensial di Bawah UUD 1945”, artikel, 2010.

Indrayana, Denny, “Negara Hukum Indonesia Pasca Soeharto: Transisi Menuju Demokrasi vs Korupsi", dalam Jurnal Konstitusi, Volume I, Nomor 1, Juli 2004.

M. Ananda B. Kusuma, R., "Sistem Pemerintahan Indonesia”, artikel dalam Jurnal Konstitusi, Volume I, Nomor 1, Juli 2004.

M. Hadjon, Philipus, "Pengkajian Ilmu Hukum Dogmatik”, artikel dalam Jurnal Hukum Yuridika Nomor 6 Tahun IX, November-Desember 1994.

“"Revitalisasi Pendidikan Tinggi Hukum”, Makalah Disampaikan dalam Seminar Nasional yang Diselenggarakan oleh Senat Mahasiswa Fakultas Hukum Atma Jaya Yogyakarta, 12 Desember 1999

dkk., Pengantar Hukum Administrasi Indonesia, Gadjah Mada University Press, Yogyakarta, 2000.

Nazriyah, Riri, "Pemberhentian Jaksa Agung dan Hak Prerogatif Presiden” Jurnal Konstitusi, Volume 7 Nomor 2 Oktober 2010, Sekretariat Jenderal dan Kepaniteraan Mahkamah Konstitusi, Jakarta

Prajudi Atmosudirdjo, S., Hukum Administrasi Negara, Ghalia Indonesia, Jakarta, 1994.

Wim Voermans, 2002, Komisi Yudisial di Negara-Negara Uni Eropa, Terjemahan dari Raden voor de Rechtpraak in landen van de Europese Unie, alih bahasa Adi Nugroho dan M. Zaki Hussein, LeIP, Jakarta, 1989. 
Westra, Patriata (eds.), Ensiklopesi Administrasi, C.V. Haji Masagung, Jakarta

http://www.jimly.com/tanyajawab?, Diakses 28 Juni 2011

http://www.jimly.com/tanyajawab?page=977, Diakses 28 Juni 2011

http://yancearizona.wordpress.com/2008/11/12/, Diakses 2 Agustus 2011

http:/ / yancearizona.wordpress.com/2008/11/12/dibalik-konstitusionalitasbersyarat-putusan-mahkamah-konstitusi/, diakses 20 September 2011

http://yusril.ihzamahendra.com/2010/08/08/, dikases 2 Januari 2011

http://yusril.ihzamahendra.com/2010/08/27/permohonan-uji-materil-uuKejaksaan-ke-mk/, diakses 1 Juli 2011

Undang-Undang Dasar Negera Republik Indonesia 1945 (UUDNRI 1945)

UUD Amerika Serikat.

The Frances Constitution of 1958

Konstitusi Republik Kelima Perancis 1958

Konstitusi Afrika Selatan

Konstitusi Korea Selatan

Konstitusi Republik Federal Jerman

Undang-Undang Nomor 15 Tahun 1961 tentang Ketentuan-Ketentuan Pokok Kejaksaan (LN 1961 No. 254)

Undang-Undang Nomor 14 Tahun 1985 tentang Mahkamah Agung (LN1985 No. 73, TLN No. 3316)

Undang-Undang Nomor 5 Tahun 1986 tentang Peradilan Tata Usaha Negara (LN 1986 No. 77, TLN No. 3344)

Undang-Undang Nomor 5 Tahun 1991 tentang Kejaksaan Republik Indonesia (LN 1991 No. 59; TLN No. 3451)

Undang-Undang Nomor 28 Tahun 1999 tentang Penyelenggaraan Negara Yang Bersih dan Bebas dari Korupsi, Kolusi dan Nepotisme (LN 1999 No. 35, TLN No. 4312)

Undang-Undang Nomor 43 tahun 1999 tentang Perubahan Atas Undang-Undang Nomor 8 tahun 1974 tentang Pokok-Pokok Kepegawaian (LN 1999 No. 50, TLN No. 4327)

Undang-Undang Nomor 24 Tahun 2003 tentang Mahkamah Konstitusi (LN 2003 No. 98, TLN No. 4316)

Undang-Undang Nomor 9 Tahun 2004 tentang Perubahan Atas Undang-Undang Nomor 5 Tahun 1986 tentang Peradilan Tata Usaha Negara (LN 2004 No. 35, TLN No. 4380)

Undang-Undang Nomor 16 Tahun 2004 tentang Kejaksaan Republik Indonesia (LN 2004 No. 67, TLN No. 4401) 
Undang-Undang Nomor 22 Tahun 2004 tentang Komisi Yudusial (LN 2004 No. 89, TLN No. 4415)

Undang-Undang Nomor 14 Tahun 2008 tentang Keterbukaan Informasi Publik (LN 2008 No. 74, TLN No. 4826)

Undang-Undang Nomor 3 Tahun 2009 tentang Perubahan Ke Dua Atas UndangUndang Nomor 14 Tahun 1985 tentang Mahkamah Agung (LN 2009 No. 3, TLN. 4958)

Putusan Mahkamah Konstitusi Nomor 49/PUU-VIII/2010 Tentang Pengujian Undang-Undang Nomor 16 Tahun 2004 Tentang Kejaksaan RI. 